\title{
Job Turnover and Divorce
}

Philip N. Cohen

University of Maryland

August 8, 2017

\begin{abstract}
$\underline{\text { Abstract }}$
Inspired by Pugh (2015), this paper explores the connection between work and couple stability, using a new combination of data from the Current Population Survey (CPS) and the American Community Survey (ACS). I test the association between job turnover, a contextual variable, and divorce at the individual level. Results show that people who work in jobs with high turnover rates - that is, jobs which many people are no longer working in one year later - are also more likely to divorce. One possible explanation is that people exposed to lower levels of commitment from employers, and employees, exhibit lower levels of commitment to their own marriages
\end{abstract}

A replication package including Stata code, raw data, and codebooks used for this analysis is available in the OSF project associated with this paper, at: osf.io/h68b5. DOI 10.17605/OSF.IO/H68B5. 


\section{Introduction}

In The Tumbleweed Society, Pugh (2015) explores the relationship between commitments at work - between employers and employees - and those at home, between partners. She finds no simple relationship such that, for example, people who feel their employers owe them nothing also have low commitment to their spouses. Rather, there is a complex web of commitments, and views of what constitutes an honorable level of commitment in different arenas. This paper is inspired by that discussion, and explores one possible connection between work and couple stability, using a new combination of data from the Current Population Survey (CPS) and the American Community Survey (ACS).

In a previous paper I analyzed predictors of divorce using data from the ACS, to see whether economic indicators associated with the Great Recession predicted the odds of divorce (Cohen 2014). Because of data limitations, I used state-level indicators of unemployment and foreclosure rates to test for economic associations. Because the ACS is cross-sectional, and divorce is often associated with job instability, I could not use individual-level unemployment to predict individual-divorce, as others have done (see review in Cohen 2014). Further, the ACS does not include any information about former spouses who are no longer living with divorced individuals, so spousal unemployment was not available either.

Rather than examine the association between individual job change and divorce, this paper tests the association between turnover at the job level and divorce at the individual level. It asks, do people who work in jobs that people are likely to leave themselves more likely to divorce? The answer - which is yes - suggests possible avenues for further study of the relationship between commitments and stressors in the arenas of paid work and family stability. Job here turnover is a contextual variable. Working in a job people are likely to leave may simply mean people are exposed to involuntary job changes, which is a source of stress. However, it may also mean people work in an environment with low levels of commitment between employers and employees. This analysis can't differentiate potential stressors 
versus commitment effects, or identify the nature (and direction) of commitments expressed or deployed at work or within the family. But it may provide motivation for future research.

\section{Do job turnover and divorce run together?}

Because individual (or spousal) job turnover and employment history are not available in the ACS, I use the March CPS, obtained from IPUMS (Flood et al. 2015), to calculate job turnover rates for simulated jobs, identified as detailed occupation-by-industry cells (Cohen and Huffman 2003). Although these are not jobs in the sense of specific workplaces, they provide much greater detail in work context than either occupation or industry alone, allowing differentiation, for example, between janitors in manufacturing establishments versus those in government offices, which are often substantially different contexts.

Turnover is identified by individuals whose current occupation and industry combination (as of March) does not match their primary occupation and industry for the previous calendar year, which is identified by a separate question (but using the same occupation and industry coding schemes). To reduce short-term transience, this calculation is limited to people who worked at least 20 weeks in the previous year, and more than 20 hours per week. Using the combined samples from the 2014-2016 CPS files, and restricting the sample to previous-year job cells with at least 25 respondents, I end up with 927 job cells. Note that, because the cells are national rather than workplace-specific, the size cutoff does not restrict the analysis to people working in large workplaces, but rather to common occupation-industry combinations. The job cells in the analysis include 68 percent of the eligible workers in the three years of CPS data.

For descriptive purposes, Table 1 shows the occupation and industry cells with the lowest and highest rates of job turnover from among those with sample sizes of 100 or more. Jobs with low turnover are disproportionately in the public sector and construction, and male-dominated (except schoolteachers); they are middle class and working class jobs. The high-turnover jobs, on the other hand, are in service industries (except light truck drivers) and are more female-dominated (Cohen 2013). By this simple 
definition, high-turnover jobs appear similar to precarious jobs as described by Kalleberg (2013) and others.

Table 1. Jobs with lowest and highest rates of annual turnover, 2014-2016

\begin{tabular}{|c|c|c|c|c|c|}
\hline Occ & Ind & $N$ & Occupation & Industry & Turnover \\
\hline \multicolumn{6}{|l|}{ Lowest } \\
\hline 3850 & 9470 & 908 & Police officers & Justice, public order, safety & .015 \\
\hline 3740 & 9470 & 394 & Firefighters & Justice, public order, safety & .022 \\
\hline 6220 & 0770 & 136 & Brick masons & Construction & .036 \\
\hline 2310 & 7860 & 4147 & Elementary/middle teachers & Elementary/secondary schools & .047 \\
\hline 6330 & 0770 & 199 & Drywall installers & Construction & .054 \\
\hline 6230 & 0770 & 1289 & Carpenters & Construction & .055 \\
\hline 3800 & 9470 & 500 & Bailiffs and correction officers & Justice, public order, safety & .059 \\
\hline 2100 & 7270 & 891 & Lawyers & Legal services & .061 \\
\hline 2015 & 9470 & 138 & Probation officers & Justice, public order, safety & .063 \\
\hline \multicolumn{6}{|l|}{ Highest } \\
\hline 4040 & 8690 & 118 & Bartenders & Drinking places & .287 \\
\hline 4720 & 5380 & 195 & Cashiers & Department/discount stores & .289 \\
\hline 9130 & 0770 & 198 & Light truck drivers & Construction & .291 \\
\hline 3255 & 8270 & 262 & Registered nurses & Nursing care facilities & .294 \\
\hline 4760 & 5170 & 163 & Retail salespeople & Clothing stores & .299 \\
\hline 5700 & 7270 & 139 & Secretaries & Legal services & .300 \\
\hline 4700 & 5275 & 143 & Retail supervisors & Sporting goods, camera, hobby/toy stores & .304 \\
\hline 4760 & 5380 & 302 & Retail salespeople & Department/discount stores & .333 \\
\hline 4700 & 5090 & 147 & Retail supervisors & Gas stations & .335 \\
\hline 4760 & 4770 & 139 & Retail salespeople & Furniture/furnishing stores & .343 \\
\hline
\end{tabular}

Note: Jobs with $\mathrm{N}=100+$ in March Current Population Surveys

Although the analysis that follows is limited to the CPS years 2014-2016 and the 2015 ACS, for context Figure 1 shows the percentage of workers who changed jobs each year, as defined above, from 1990 through 2016. Note that job changing, which is only identified for employed people, fell during the previous two recessions - especially the Great Recession that began in 2008 - perhaps because people who lost jobs would in better times have cycled into a different job instead of being unemployed. In the last two years job changing has been at relatively high levels (although note that CPS instituted a new industry coding scheme in 2014, with unknown effects on this measure). In any event, this phenomenon has not shown dramatic changes in prevalence for the past several decades. 


\section{4}

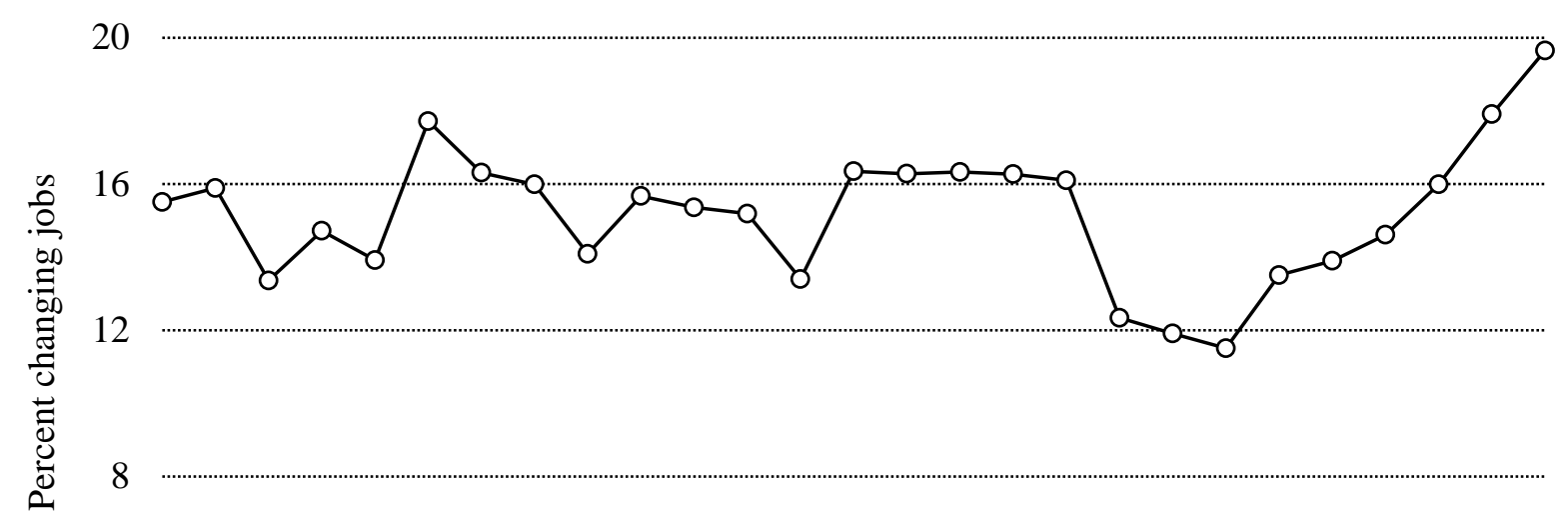

4

0

$\begin{array}{llllllllllllll}1990 & 1992 & 1994 & 1996 & 1998 & 2000 & 2002 & 2004 & 2006 & 2008 & 2010 & 2012 & 2014 & 2016\end{array}$

Year

Figure 1. Percentage of workers (20+ weeks, >20 hours per week) whose jobs (occupation-byindustry cells) in March differed from their primary job in the previous calendar year.

Using the occupation industry codes from the CPS and ACS, which match for the years under study, I attach the job turnover rates from the 2014-2016 CPS data to individuals in the 2015 ACS (Ruggles et al. 2015). The analysis then uses the same modeling strategy at that used in Cohen (2014). Using the marital events variables in the ACS (Cohen 2015), I combine people, age 18-64, who are currently married (excluding those who got married in the previous year) and those who have been divorced in the previous year, and model the odds that individuals are in the divorced group. In this paper I essentially add the job turnover measure to the basic analysis in Cohen (2014, Table 3) (the covariates used here are the same except that I added one category to the education variable).

One advantage of the ACS data structure is that the occupation and industry questions refer to the “current or most recent job," so that people who are not employed at the time of the survey still have job 
characteristics recorded. Although that has the downside of introducing information from jobs in the distant past for some respondents, it has the benefit of including relevant job information for people who may have just quit (or lost) jobs as part of the constellation of events involved in their divorce (for example, someone who divorces, moves to a new area, and commences a job search). If job characteristics have an effect on the odds of divorce, this information clearly is important. The ACS sample size is 581,891, 1.7 percent of whom reported having divorced in the previous year.

Results from two multivariate regression analyses are presented in Table 2. The first model predicts the turnover rate in the ACS respondents' job, using OLS regression. It shows that, ceteris paribus, turnover rates are higher in the jobs held by women, younger people (the inflection point is at age 42), people married more recently, those married few times, those with less than a BA degree, Blacks, Asians, Hispanics, and immigrants. Thus, job turnover shows patterns largely similar to labor market advantage generally.

Most importantly for this paper, divorce is more likely for those who most recent job had a higher turnover rate, as defined here. In a reduced model (not shown), with just age and sex, the logistic coefficient on job turnover was 1.39; the addition of the covariates in Table 2 reduced that effect by 39 percent, to .84, as shown in the second model. Beyond that, job turnover is predicted by some of the same characteristics as those associated with increased odds of divorce. Divorce odds are lower after age 25, with additional years of marriage, with a BA degree, and for Whites. However, divorce is less common for Hispanics and immigrants. (The higher divorce rates for women in the ACS are not well understood; this is a self-reported measure, not a count of administrative events.) 
Table 2. Regression coefficients for job turnover and divorce on individual variables

\begin{tabular}{|c|c|c|}
\hline & Job turnover (OLS) & Divorce (logit) \\
\hline Job turnover & $\overline{--}$ & $\begin{array}{l}0.843^{*} \\
{[3.64]}\end{array}$ \\
\hline Female & $\begin{array}{l}0.0143^{*} \\
{[55.86]}\end{array}$ & $\begin{array}{l}0.127^{*} \\
{[4.03]}\end{array}$ \\
\hline Age & $\begin{array}{c}-0.00183^{*} \\
{[-18.77]}\end{array}$ & $\begin{array}{c}0.0393^{*} \\
{[3.64]}\end{array}$ \\
\hline Age-squared & $\begin{array}{c}0.0000218^{*} \\
{[20.27]}\end{array}$ & $\begin{array}{c}-0.000783^{*} \\
{[-6.45]}\end{array}$ \\
\hline \multicolumn{3}{|l|}{ Marital history } \\
\hline Years married & $\begin{array}{c}-0.000144^{*} \\
{[-7.67]}\end{array}$ & $\begin{array}{c}-0.00856^{*} \\
{[-4.00]}\end{array}$ \\
\hline Married once & -- & -- \\
\hline Married twice & $\begin{array}{c}0.00160^{*} \\
{[4.19]}\end{array}$ & $\begin{array}{c}0.443^{*} \\
{[11.62]}\end{array}$ \\
\hline Married 3+ times & $\begin{array}{c}0.00265^{*} \\
{[3.78]}\end{array}$ & $\begin{array}{c}0.763^{*} \\
{[11.78]}\end{array}$ \\
\hline \multicolumn{3}{|l|}{ Education } \\
\hline Less than high school & -- & -- \\
\hline High school & $\begin{array}{c}0.00948^{*} \\
{[18.87]}\end{array}$ & $\begin{array}{c}0.0374 \\
{[0.71]}\end{array}$ \\
\hline Some college & $\begin{array}{c}0.00338^{*} \\
{[6.43]}\end{array}$ & $\begin{array}{c}-0.00128 \\
{[-0.03]}\end{array}$ \\
\hline BA or higher & $\begin{array}{c}-0.0247^{*} \\
{[-49.35]}\end{array}$ & $\begin{array}{l}-0.372^{*} \\
{[-6.53]}\end{array}$ \\
\hline \multicolumn{3}{|l|}{ Race/ethnicity } \\
\hline Black & $\begin{array}{c}0.00925^{*} \\
{[18.30]}\end{array}$ & $\begin{array}{l}0.285^{*} \\
{[6.53]}\end{array}$ \\
\hline American Indian & $\begin{array}{c}0.00147 \\
{[1.26]}\end{array}$ & $\begin{array}{l}0.307^{*} \\
{[3.34]}\end{array}$ \\
\hline Asian & $\begin{array}{l}0.0119^{*} \\
{[20.72]}\end{array}$ & $\begin{array}{l}-0.208 \\
{[-2.23]}\end{array}$ \\
\hline Pacific Islander & $\begin{array}{c}0.00229 \\
{[0.91]}\end{array}$ & $\begin{array}{l}0.228 \\
{[1.06]}\end{array}$ \\
\hline Hispanic & $\begin{array}{c}-0.00445^{*} \\
{[-9.95]}\end{array}$ & $\begin{array}{l}-0.0562 \\
{[-1.12]}\end{array}$ \\
\hline Foreign-born & $\begin{array}{c}0.00302^{*} \\
{[7.24]}\end{array}$ & $\begin{array}{l}-0.312^{*} \\
{[-5.56]}\end{array}$ \\
\hline Constant & $\begin{array}{c}0.192^{*} \\
{[88.18]}\end{array}$ & $\begin{array}{c}-4.102^{*} \\
{[-16.47]}\end{array}$ \\
\hline Observations & 581,891 & 581,891 \\
\hline Adjusted $R^{2}$ & 0.048 & \\
\hline
\end{tabular}

$t$ statistics in brackets; * $\mathrm{p}<0.005$; divorce model has robust standard errors. 
To illustrate the relationship between job turnover and the probability of divorce, Figure 2 shows the average predicted probability of divorce (from the second model in Table 2) for each of the jobs represented, with markers scaled according to sample size and a regression line similarly weighted. Below 20 percent job turnover, people are generally predicted to have divorce rates less than 2 percent per year, with predicted rates rising to 2.5 percent at high turnover rates (40 percent).

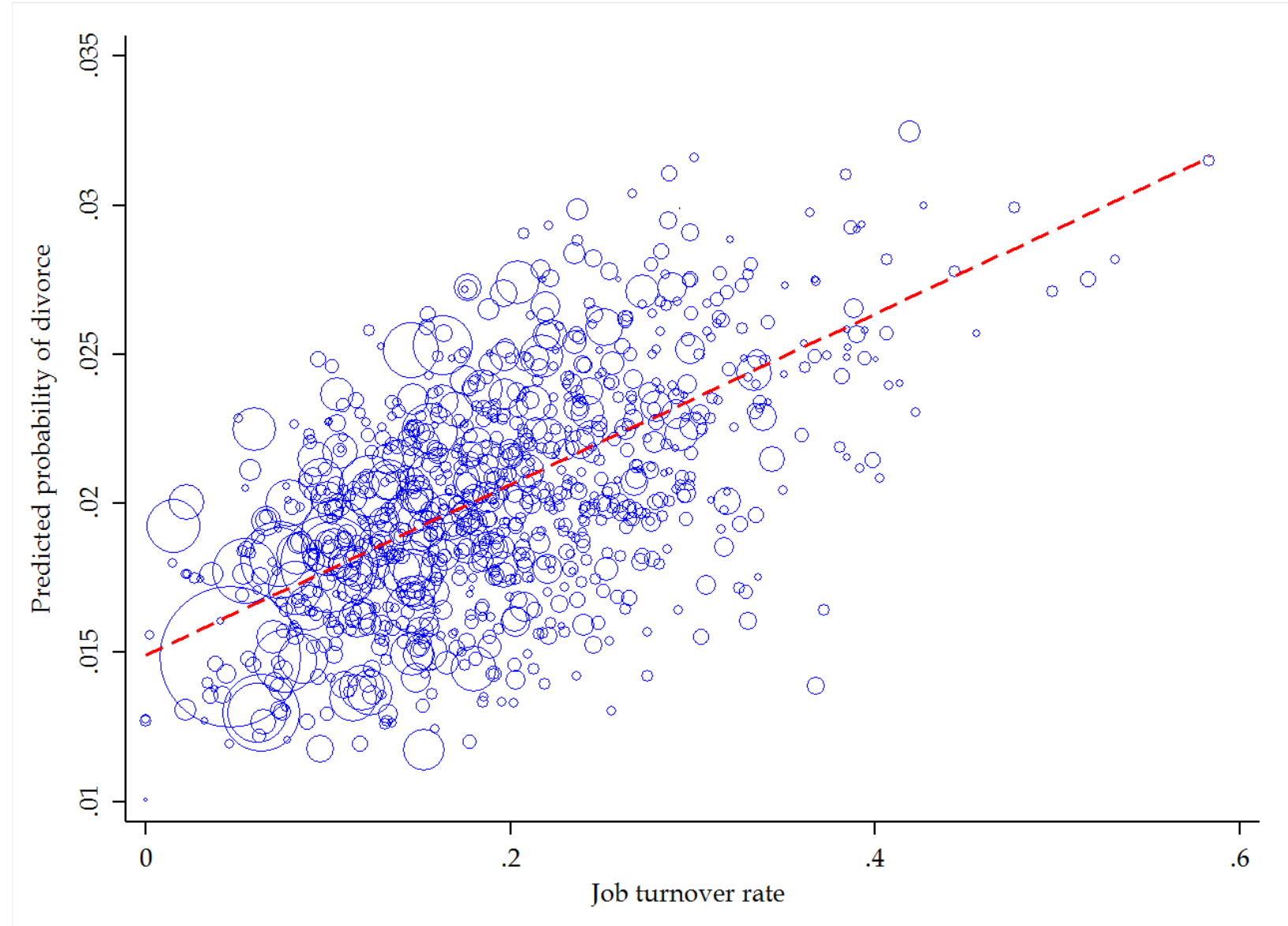

Figure 2. Average predicted probability of divorce within jobs (from logistic model in Table 2), by turnover rate. Markers are scaled according to sample size, and the linear regression line shown is weighted by sample size.

\section{Conclusion}

People who work in jobs with high turnover rates - that is, jobs which many people are no longer working in one year later - are also more likely to divorce. A reading of this inspired by Pugh's (2015) 
analysis might be that people exposed to lower levels of commitment from employers, and employees, exhibit lower levels of commitment to their own marriages. Another, noncompeting explanation would be that the stress or hardship associated with high rates of job turnover contributes to difficulties within marriage. Alternatively, the turnover variable may simply be statistically capturing other aspects of job quality that affect the risk of divorce, or there are individual qualities by which people select into both jobs with high turnover and marriages likely to end in divorce. This is a preliminary analysis, intended to raise questions and offer some avenues for analyzing these questions in the future.

\section{References}

Cohen, Philip N. 2013. “The Persistence of Workplace Gender Segregation in the US.” Sociology Compass 7 (11): 889-99. doi:10.1111/soc4.12083.

Cohen, Philip N. 2014. “Recession and Divorce in the United States, 2008-2011.” Population Research and Policy Review 33 (5): 615-28. doi:10.1007/s11113-014-9323-z.

Cohen, Philip N. 2015. "How We Really Can Study Divorce Using Just Five Questions and a Giant Sample.” Family Inequality. July 22. https://familyinequality.wordpress.com/2015/07/22/how-we-reallycan-study-divorce/.

Cohen, P. N., and M. R. L. Huffman. 2003. "Individuals, Jobs, and Labor Markets: The Devaluation of Women’s Work.” American Sociological Review 68 (3): 443-63. doi:10.2307/1519732.

Kalleberg, Arne L. 2013. Good Jobs, Bad Jobs: The Rise of Polarized and Precarious Employment Systems in the United States 1970s to 2000s. New York, NY: Russell Sage Foundation.

Steven Ruggles, Katie Genadek, Ronald Goeken, Josiah Grover, and Matthew Sobek. Integrated Public Use Microdata Series: Version 6.0 [dataset]. Minneapolis: University of Minnesota, 2015.

http://doi.org/10.18128/D010.V6.0.

Sarah Flood, Miriam King, Steven Ruggles, and J. Robert Warren. Integrated Public Use Microdata Series, Current Population Survey: Version 4.0. [dataset]. Minneapolis: University of Minnesota, 2015. http://doi.org/10.18128/D030.V4.0.

Pugh, Allison J. 2015. The Tumbleweed Society: Working and Caring in an Age of Insecurity. 1 edition. New York, NY: Oxford University Press. 